\title{
Chapter IVA \\ The Shift \\ from the Old World to the New
}

n one of the last issues of Sovremennye zapiski, Iurii Rapoport, in
an essay titled "The End of the [Community] Abroad" (Konets zarubezh'ia), reasserts the consensus account of Russia Abroad as representing all Russians and forming "a state without territory" (gosudarstvo bez territorii). ${ }^{1}$ But he also points to the changes that, inevitably, have taken place over time both in the emigration and in Soviet Russia, commenting that these changes are making the old émigré longings for a return to a restored "homeland" less realistic:

Notions that somehow, underneath the outer layers of the Soviet people, [there is] a Russian people who continue to be as they used to be is becoming ever more a fantasy; more and more in Russia there is a numerical preponderance of those who have simply not seen, and do not know the past. $^{2}$

The émigrés of the First Wave were soon to experience another momentous change, the Second World War, during which the cultural center of the emigration, Paris, was occupied (in 1940). Whether in anticipation, or as a result, many of them relocated to America, especially to New York. Then, in 1941, the Germans invaded the Soviet Union and the homeland became an ally of the new host country. These turns of events revived patriotic feelings among émigré Russians. Further, the fact that Russians in the Soviet Union and abroad shared the same cause was widely felt to make more possible once again their dreams of a "homecoming."

In this new center of the emigration, New York, the war had no direct impact and conditions were more favorable for intellectual life. Conse-

1 Sovremennye zapiski 69 (1939): 374.

2 Ibid., 380. 
quently, the Russian recent arrivals were able to serve some needs of the imperiled Russian community in Europe. The appearance of Novyi Zhurnal (The New Journal) in New York, starting in 1942, was a major landmark in the cultural geography of the Russian diaspora. Its planning had begun in 1941, at the time when all of Europe was engaged in a terrible war with Hitler and the homeland was in grave danger. Russian émigrés turned towards it as they struggled to survive in Europe. The history of the creation of Novyi Zhurnal, intended to continue, with some modifications, the now defunct Paris-based Sovremennye zapiski (1920-1940), revealed the radical changes in the diaspora during the wartime and the later postwar years. The new journal provided continuity for the émigré tradition, giving an active role to the first-wave diaspora, thus creating an important publication venue at the time when the European journals and publishers were disabled. The desperate situation for the Russians in Europe is brought out in a letter of Mark Aldanov (pseudonym of Mark Aleksandrovich Landau) to Mikhail Karpovich of January 1941, in which he endorses the idea of a journal to forge cultural links across the Atlantic.

It goes without saying that I am completely in agreement with you on the necessity of trying to create a new Russian journal. From the very beginning - that is to say, from the moment of the French catastrophe-it was clear to me that the only place where Russian work could be continued is America, and that our role is not to let that work die out completely. You are right that the question comes down to where we can find money. ${ }^{3}$

The journal began publication in 1942 and the struggle for funds continued throughout the war period. In a letter of 8 September 1943 to Professor Philip Mosely, who wrote of his efforts to secure funding for the Bakhmeteff Archive from the Rockefeller, ACLS, and other foundations, Karpovich acknowledges the importance of this moment in history: "The difficulties about which you write I too can well imagine. This irks me, since I think that a sober and critical approach to all problems concerning Russia is needed now more than ever."

3 Bakhmeteff Archive, Columbia University. Ms. Coll. M. A. Aldanov. Letter to M. M. Karpovich, 18/1/41.

4 Bakhmeteff Archive, Columbia University. Ms. Coll. M. M. Karpovich, Box 2. 
Novyi Zhurnal's recognition of its importance is clear from the editorial statement in the first issue of 1942, which claims that this is the only Russian “'thick journal' (tolstyi zhurnal) in the world outside Russia." The journal would be open to writers of all ideological persuasions, the editorial continues, except for those expressing sympathies "with national socialism or Bolshevism."5 The journal in effect took over the role of Sovremennye zapiski, which posited émigré culture as the heir and guardian of the Russian national tradition, and it planned to continue that journal's main approach, although with significant changes. From the outset, the editors, M. Aldanov and M. Tseitlin, were attuned to the new historical circumstances. They insisted that it was their duty to say what Russians in the homeland could not express regarding Soviet politics, but at the same time they urged the old emigration to forget their differences and unite in order to aid the Soviet Union in her struggle with fascism, continuing: "Now it is possible and necessary to forget about the quarrels of 1917 and the ensuing epoch, that is now in the past."6

At the same time, the editors made it clear that the journal would differ from its French predecessor, because politics rather than culture would be its foremost concern: "Sovremnnye zapiski, Russkie zapiski and those older journals, whose traditions we would like to follow, were published during peace time and were able, naturally, to devote greater space to larger cultural, philosophical, and scholarly questions." ${ }^{\prime}$ However, the editors expressed the hope that this weighting could be reversed later.

At the time, however, the journal felt freer to express political views than had been possible in war-time Europe. In a letter to Sergei Aleksandrovich Konovalov in Oxford of 8 December 1944, Mikhail Karpovich draws attention to this difference suggesting that "You probably have noticed that we here are able to afford ourselves a measure of freedom in our critical pronouncements that, it is my impression would hardly be possible for you," but added tactfully: "Perhaps I am mistaken."

\footnotetext{
Novyi Zhurnal 1 (1942): 5.

Ibid., 7.

Ibid.

8 Bakhmeteff Archive. Ms. Coll. M. Karpovich, Box 2.
} 
Later, after the war, the numbers in the Russian community in New York swelled as immigrants arrived, from what became known as the Second Wave of emigration from Soviet Russia, most of them individuals displaced by the war. This admixture exacerbated the generational differences, challenging the notion that there could be a single culture for Russia Abroad and the Soviet Union and forcing writers to come up with a new definition of the collective diasporic identity. The disagreements over this could be seen as illustrating the general trend in diasporas identified by the expert on this, Khachig Tölölyan, what he calls "'the traces of struggles and contradictions within ideas and practices of collective identity, of homeland and nation." "Whereas the continuity and preservation of the national tradition had been the foremost concern of the First Wave (1920-1939), as it defined itself vis-à-vis the homeland, now that charge underwent a qualitative change. The selfdefinition of the diaspora, of its relation to the host country and to the homeland, became more complex, especially when its historic position had been radically altered after the Yalta Agreement and the ensuing Cold War.

During the Cold War, in meeting the challenge of self-definition, a complex split-level rift developed that made the running of the journal a matter of inordinate diplomatic skill, vision and patience. For one thing, the generational differences remained profound: the older émigrés who were still in Europe or had come to the US from there felt superior both to the New World intellectuals and to the newcomers who began to flock to the United States when the war was over. As late as 1953, Vasilii Ianovskii wrote in a letter to Fedor Stepun:

We used to complain about the book trade in Paris, but now things have really gone downhill: there is nowhere to publish and no one is reading. I would like to try an American journal, but for a Russian it makes no sense: there are no intelligent readers. Once there was our émigré culture. It was possible to say anything-everyone would understand it. Where has that culture gone?10

9 Khachig Tölölyan, “The Nation State and its Others: In Lieu of a Preface,” Diaspora 1:1 (Spring 1991): 3.

10 The Beinecke Rare Book and Ms. Library. Fedor Stepun Papers, Box 15, Folder 496. Ianowsky, V. S. 1953, n.d. 
The passage to the New World became a crossing of yet another threshold in the diasporic consciousness that reinforced a sense of nostalgia, though after the transatlantic shift the longing for Russia was combined with a nostalgia for Europe. Émigrés identified themselves as "European Russians" in the New World and felt alienated in a world that did not share their attachment for the continent, a sentiment expressed in a letter that Roman Grynberg, living in New York, wrote to Wladimir Weidle in Paris on 1 January 1947:

Here in America, only those newly-arrived people of our generation mourn for Europe. Americans think of it differently, and those who are a bit more cultured than the previous generation remember the famous words of Emerson, spoken exactly one hundred years ago: "The world is nothing; man is all ... we have listened too long to the courtly muses of Europe." [This sentence is in English in the original Russian $]^{11}$

At the same time, the émigrés in New York were confronted by a number of alternative options as they sought to work out their own identities and moral stances in postwar Europe, and one of them was in fact to reorient one's thinking away from the accustomed Eurocentric path, and even away from identification with the West. In the immediate postwar years the rise of patriotic feelings for the victorious motherland and antipathy toward the US, that had participated in the Allied effort but was not ravaged by war, contributed to the quandaries about the right direction to take. A complicating factor in the contradictory postwar political situation of the émigrés was the new status of the recently victorious Soviet Union as it beckoned them home. This further deepened the rift between the Russians in America and the Russians in Europe, whose consciousness had been transformed by the war experience. These complexities are apparent in Konovalov's report on the mood of Russian émigrés in Paris after the war, presented in an article in the 1945 issue of Novyi Zhurnal under the title "The Emigration and Soviet Power (A Questionnaire)” (Emigratsiia i sovetskaia vlast' (Anketa)). Konovalov

11 Bakhmeteff Archive, Columbia University. Ms. Coll. V. Weidle. Letter from Grynberg, Roman, Jan. 1947, n.d. 
divides the émigrés in three groups: first, the pro-Soviet group; second, those who remain staunchly opposed; and third, those who take a "wait and see" attitude. In addition, he comments that one thing is now clear: the war and the Soviet victory proved that Soviet Russia was viable as a nation and brought on a wave of patriotism. ${ }^{12}$

The expected exchange of views as the follow-up to this first communication of the questionnaire did not occur. Instead, the Paris correspondent of Novoe Russkoe Slovo published a surprising report of his February visit to Paris, which commented on the "emotional atmosphere" in Paris, following the German occupation. The European émigrés had been moved by the Soviet victory and the show of national determination that achieved the liberation of the land and of Europe, but felt that their counterparts in America and their press did not understand this.

One letter to the editor stated, "Perhaps you in America did not believe in German victory, but we saw it in France. And as we thought that the only salvation could come from Soviet Russia, we forgave her everything.... We felt closer to Stalin than to those Russians that joined Hitler hoping to overthrow the Soviet leader." ${ }^{13}$ There were others in the emigration, however, who did not share such sentiments. A decidedly anti-nostalgic stance is to be found in a poem of Vladimir Nabokov, a copy of which he sent to M. Karpovich. It introduces a much needed note of reason into this overheated situation:

Kakim by polotnom batal'nym ne iavlialas'

Sovetskaia susal'neishaia Rus'!

Kakoi by zhalost'iu dusha ni zapolnialas',

Ne poklonius', ne primirius'

So vseiu merzost'iu, zhestokost'iu i skukoi

Nemogo rabstva. Net, o net!

Eshche ia dukhom zhiv, eshche ne syt razlukoi,

Uvol'te, ia eshche poet. ${ }^{14}$

12 Novyi Zhurnal 11 (1945): 351-353.

13 Ibid., 352.

14 Bakhmeteff Archive. Columbia University. Ms. Coll. M. Karpovich. Nabokov, V. V. April or May, 1943. 
(Nabokov's own published translation of his poem, Cambridge, MA, 1944): $:^{15}$

No matter how the Soviet tinsel glitters

Upon the canvas of a battle piece;

No matter how the soul dissolves in pity,

I will not bend, I will not cease

Loathing the filth, brutality and boredom

Of silent servitude. No, No, I shout,

My spirit is still quick, still exile-hungry,

I'm still a poet, count me out!

Novyi Zhurnal was central to the cultural survival and revival of the Russian emigration in the post-war period, marking a second major stage in its history since 1917. The two historians of the Russian emigration, Gleb Struve and Marc Raeff, both point to "a qualitative shift" that occurred in the émigré status in the host countries of the US and Canada, where the situation was decidedly different from that in pre-war Berlin or Paris. The sense of inclusion and economic security in post-war North America led to a new self-consciousness among the émigrés.

While the national culture continued to have enormous importance for them, the question of how to weight the relationship between culture and politics, a subject of extensive polemics within the First Wave, underwent a definite change as the Cold War intensified (this development was foreseen by the editors in the first issue, cited above). The polarization of East and West was no longer an exclusive concern of Russians abroad, but had become an issue of world importance. This development also prompted a change in the international status of the émigrés, and can be considered as a part of the "qualitative shift" after the 1930s. Gleb Struve comments on the changing character of the emigration in his 1959 essay on "Russian Writers in Exile: Problems of an Émigré Literature."16 After a dramatic opening where he declares that "for nearly forty years Russian

15 Vladimir Vladimirovich Nabokov, no title, in Modern Russian Poetry, ed. Vladimir Markov and Merrill Sparks (Indianapolis/Kansas City/New York: Bobbs-Merrill, 1967), 479.

16 Comparative Literature. Proceedings of the Second Congress at the Univ. of North Carolina, Sept. 8-12, 1958. International Comparative Literature Association, ed. W. P. Frederich (Chapel Hill: University of North Carolina Press, 1959). 
literature has been leading a double life," Struve describes the effect of World War II and its aftermath on the emigration and how the post-war influx had "introduced new factors into the situation: among the new émigrés there were no nationally known writers. They were on the whole more politically-minded, not necessarily more principled, sometimes more militant. And intransigent, and yet in a sense more indoctrinated. It is Socialist Realism in reverse." 17

In the article, Struve also addresses the change in the social status of the émigrés, signaled earlier, as they play a more active political role than their predecessors, who often felt themselves a part of what Varshavskii named the "unnoticed generation" (nezamechennoe pokolenie): "In the thirties, especially, the émigré writers were living in a vacuum and their anti-Communist warnings sounded like a voices in the wilderness. The situation changed radically after WWII, with the result that the material situation and the social status of the exiled Russians engaged in the writing professions improved greatly, particularly in the US and within the sphere of the American influence." 18 And he pronounces Novyi Zhurnal the best Russian periodical, adding that "the future historians of Russian literature will have to consult very closely." Within some twenty years, the journal had fulfilled its intended role: in the Russian-speaking world it had become an indispensable alternative voice, social, political, and literary. The journal's success is also stressed in a letter written in 1965 by one of its then editors, Roman Gul', to Weidle in Paris: "In recent years Novyi zhurnal has been selling at an incredible rate. It all gets sold, right to the last copy."19

Weidle himself provided a witty summary of the post-war period of both the émigré and Russian literature in his essay "The Traditional and the New in Russian Literature of the 20th Century" (Traditsionnoe i novoe $v$ russkoi literature $X X$ veka), which appeared in the stocktaking volume Russian Literature in Emigration (Russkaia literatura $v$ emigratsii): "It [the border] existed, and it did not exist. There were 'Stalin-Lenin' prizes, there was junk; and on our side too there was junk. But there were never two literatures; there was one literature of the twentieth century." ${ }^{20}$

17 Ibid., 14.

18 Ibid., 7.

19 Bakhmeteff Archive, Coll. V. Weidle. Letter, Gul' Roman Borisovich. 4 December 1965.

20 Russkaia literatura v emigratsii, ed. N. Poltoratsky (Pittsburgh, PA: Pittsburgh University Press, 1972), 13. 
A younger critic, Nikolai Andreev, also writing in this volume, strikes a refreshing note of self-affirmation of the Second Wave as he offers recognition of the contribution of the new immigrants from the Soviet Union, who brought their knowledge of Stalin's Russia and a sense of Russian reality, which "imparted new life energy into the entire Russian literary community abroad (pridalo zhiznennost' vsemu russkomu literaturnomu zarubezh'iu):

The Second-Wave emigration, whose precise numbers are not known, very quickly integrated into the community abroad, which was in part "rejuvenated" by it ... although many of the new émigrés responded more readily and out of habit to political summons that had become particularly attractive since the "Cold War" began. ${ }^{21}$

The Paris-based poet Yuri Terapiano, writing in his introduction to a collection of émigré poetry, presents the shift in collective identity of the post-war Diaspora as seen from the perspective of a poet familiar with both waves. Here he comments on the differences between the "Paris Note" in interwar poetry and the postwar poets, concluding that, despite this, a unity of purpose had been achieved: "It has taken several years for the combined efforts of both 'those who had come before' and the 'newcomers' to win out the fight for creative freedom in post-war emigration." The sense of mission of the postwar Diaspora is reasserted here. They saw the creative freedom from the kind of "social command" imposed on Soviet writers as the decisive advantage of Russian writers abroad and a criterion for vindicating their emigration. As Terapiano put it: "And then it suddenly became clear to everyone that the mission of poetry abroad would constitute one of those achievements by which, in the future, it [the community] would be able to justify its existence."22

The consensus has been that mission of Novyi Zhurnal in the postwar diaspora was achieved. In the conclusion to his history of the Russian diaspora, Marc Raeff wrote that "the intellectuals of Russia Abroad had perpetuated the tradition of the Russian intelligentsia; they offered a moral (political) critique of conditions at home, and served as chan-

21 Ibid., 29.

22 Muza diaspory. Izbrannye stikhi zarubezhnykh poetov. 1920-1960 (Frankfurt am Main: Possev, 1960), 22. 
nels for the importation and integration of Western knowledge and values." 23

The "conversation" across the Soviet border that had largely ceased in 1925 picked up again and had an impact on émigré activity and their sense of mission. Soviet writers for their part also responded to the emigration, but most often negatively. However, as Roman Gul put it in another letter to Weidle about Novyi Zhurnal, this one of 2 January 1970:

\begin{abstract}
Now the situation of the journal, in my view, has become more solid. It has helped considerably, of course, that Kochetov is "advertising" me in his novels, and Sergei Mikhalkov is declaring to the entire [Writers'] Union that Novyi zhurnal is "an émigré literary den [of thieves]."24
\end{abstract}

The "homecoming," then, during the Cold War, began to seem an ever more distant possibility; but the situation started to change. Beginning in the mid-1970s, large numbers of Soviet citizens were permitted to emigrate and many of them ended up in Europe or the US, forming the Third Wave. In theory, only Jews and Armenians "seeking to reunite" with family members could leave. In practice, many others emigrated, including dissidents, scientists, writers, artists, human-rights activists, and other "undesirables." In other words, a sizeable proportion were intellectuals or highly educated. Once again the cultural life of Russia Abroad was "rejuvenated," but the new influx also strengthened their cultural links with the homeland. And vice versa-émigré writings were now circulating in Soviet underground publications. However, it took Mikhail Gorbachev's accession to power in 1985 to really break down the barriers between the two versions of Russian culture and combine them into one.

23 Raeff, Russia Abroad, 197.

24 The references are, respectively, to Vsevolod Kochetov, generally labeled a Soviet "hard-liner," whose most famous novel, The Zhurbins (Zhurbiny) of 1952, features a dynasty of inspired shipbuilding workers in Leningrad, and Sergei Mikhalkov, author of the text of the Soviet national anthem. Citation from the Bakhmeteff Archive, Columbia University. Ms. Coll. V. Weidle. 